\title{
Comparison of the Levator Hiatal Area
}

\author{
Perbandingan Area Hiatal Levator Ani
}

\author{
Muhammad E Juniarto, Fernandi Moegni \\ Department of Obstetrics and Gynecology \\ Faculty of Medicine Universitas Indonesia/ \\ Dr. Cipto Mangunkusumo Hospital \\ Jakarta
}

\begin{abstract}
Objective: To determine the relationship of the levator hiatal area among nulliparous, primiparous, and multiparous women so that we can assess the prevalence of avulsion.

Method: A cross-sectional study design was used by evaluating the transperineal ultrasound results of all nulliparous, primiparous, and multiparous women in the Obstetrics and Gynecology Clinic of Dr. Cipto Mangunkusumo hospital from May to December 2015. We analyzed the data through SPSS using one way ANOVA to compare the levator hiatal dimension among the groups of women during Valsava maneuver and at rest.
\end{abstract}

Result: There were significant differences in levator hiatal area among nulliparous, primiparous, and multiparous women during Valsalva maneuver and at rest, which the mean (SD) was 22.26 (5.45) $\mathrm{cm}^{2}(\mathrm{p}=0.028)$ and $10.70(2.26) \mathrm{cm}^{2}(\mathrm{p}=0.012)$, respectively. Levator ani muscle avulsion was occurred in 1 out of $46(2.2 \%)$ women from the primiparous and multiparous group.

Conclusion: There are significant differences in levator hiatal area during Valsalva and at rest among the groups.

[Indones J Obstet Gynecol 2016; 4-4: 208-211]

Keywords: avulsion, levator hiatal area, multiparous, nulliparous, primiparous

\begin{abstract}
Abstrak
Tujuan: Untuk mengetahui hubungan area hiatal otot levator ani perempuan nulipara, primipara dan multipara saat istirahat/kontraksi dan manuver Valsalva serta mengetahui prevalensi kejadian avulsi.

Metode: Penelitian ini menggunakan studi potong lintang dengan melihat hasil pemeriksaan USG transperineal yang dilakukan pada pasien perempuan nulipara, primipara dan multipara yang datang ke poli Obstetri dan Ginekologi RSUPN Dr. Cipto Mangunkusumo pada bulan Mei-Desember 2015. Kami melakukan analisis data dengan SPSS menggunakan one way ANOVA untuk membandingkan area levator hiatal antara kelompok pasien selama manuver Valsalva dan saat istirahat.

Hasil: Terdapat perbedaan bermakna untuk area hiatal otot levator ani pada saat Valsalva maupun istirahat untuk ketiga kelompok penelitian dengan ( $p=0.028$ dan $p=0.012)$. Saat Valsalva, perbedaan area hiatal otot levator ani ditemukan pada kelompok nulipara dan multipara dengan perbedaan rerata (standar deviasi) yaitu 22,26 $(5,45) \mathrm{cm}^{2}$. Saat istirahat, perbedaan area hiatal otot levator ani ditemukan pada kelompok nulipara dan multipara dengan perbedaan rerata (standar deviasi) yaitu $10,70(2,26) \mathrm{cm}^{2}$. Avulsi otot levator ani terjadi pada 1 dari 46 (2,2\%) pada perempuan primipara dan perempuan multipara.
\end{abstract}

Kesimpulan: Terdapat perbedaan bermakna untuk area hiatal otot levator ani pada saat maneuver Valsalva maupun istirahat untuk ketiga kelompok penelitian.

[Maj Obstet Ginekol Indones 2016; 4-4: 208-211]

Kata kunci: area hiatal levator ani, avulsi, multipara, nulipara, primipara

Correspondence: Muhammad Eric Juniarto, dr.eric79@gmail.com

\section{INTRODUCTION}

Pelvic floor dysfunction becomes major public health problem, whereas, around $23 \%$ of women suffer from this condition worldwide. Pelvic floor dysfunction significantly decreases the quality of life due to many symptoms, such as constipation, urinary or anal incontinence, chronic pelvic pain, and urogenital prolapse. ${ }^{1}$

An important component of pelvic floor system is levator ani muscle; therefore, trauma to this muscle is related to pelvic floor disorders. Avulsion of the levator ani muscle is a common consequence of vaginal childbirth ${ }^{2}$ affecting between $13 \%$ and $36 \%$ of women. In general, it happens after the first vaginal delivery. ${ }^{2-9}$ In nulliparas, no avulsions were observed. ${ }^{10}$

A levator avulsion results from the detachment of inferior pubic rami on puborectalis muscle. ${ }^{11}$ The striated muscles of levator ani form an essential component of structural support mechanism in the pelvic floor. Unlike other skeletal muscles, the levator ani muscle differs because it maintains constant tone, except during voiding, defecation, and the Valsalva maneuver. It has the capability to con- 
tract rapidly during sudden increase of abdominal pressure, for example on a cough or sneeze or physical activity; thereby, it will reduce the risk of incontinence and pelvic organ prolapse (POP). Paradoxically, it has to stretch during parturition even beyond its limits in order to allow the passage of baby. However, it has to contract after delivery to preserve the normal function. ${ }^{12}$ Levator anal muscle is very susceptible to the stretch-induced injury. During the stretch, the extent of injury is proportional to the work performed on the muscle. ${ }^{13}$ Therefore, this study aims to determine the relationship of the levator hiatal area among nulliparous, primiparous, and multiparous women so that we can assess the prevalence of avulsion.

\section{METHOD}

A cross sectional study design was used by evaluating the patients' transperineal ultrasound results. This study used consecutive sampling method with a total of 69 patients. We recruited the women coming to Obstetrics and Gynecology Clinic Dr. Cipto Mangunskusumo hospital from May to December 2015. We exclude the pregnancy women, women with history of pelvic malignancy, history of pelvic reconstructive surgery, history of pelvic trauma, and inability to contract pelvic floor muscles correctly. We described the characteristics demography of women and analyzed using one way ANOVA to compare the levator hiatal dimension among the groups of women during Valsalva maneuver and at rest. We analyzed the data using SPSS.

\section{RESULTS}

Of the 69 patients assessed, there were 23 women in each group of nulliparous, primiparous, and multiparous. Demographic characteristics of the patients were presented in Table 1.

Levator hiatal dimension measured at Valsalva maneuver was presented in Table 2 . The data dis- tribution on levator hiatal area were normal among all groups. The ANOVA result showed the significant differences on levator hiatal area among nulliparous, primiparous, and multiparous women during Valsalva maneuver $(\mathrm{p}=0.012)$.

Table 2. Comparisons of Levator Hiatal Dimensions Measured at Valsalva Maneuver

\begin{tabular}{lccc}
\hline \hline & N & Mean (SD) & p value \\
\hline Nulliparous group & 23 & $17.72(4.93)$ & 0.012 \\
Primiparous group & 23 & $18.69(5.37)$ & \\
Multiparous group & 23 & $22.26(5.45)$ & \\
\hline \hline
\end{tabular}

Table 3 presented levator hiatal dimension measured at rest. Among all groups, levator hiatal measurement was normally distributed. The ANOVA results indicated that there were significant differences on levator hiatal area among nulliparous, primiparous, and multiparous women at rest $(\mathrm{p}=0.012)$.

Table 3. Comparisons of Levator Hiatal Dimensions Measured at Rest

\begin{tabular}{lccc}
\hline \hline & N & Mean (SD) & p value \\
\hline Nulliparous group & 23 & $10.00(2.17)$ & 0.028 \\
Primiparous group & 23 & $10.70(2.26)$ & \\
Multiparous group & 23 & $11.96(2.86)$ & \\
\hline \hline
\end{tabular}

Of 46 primiparous and multiparous women, there was $1(2.2 \%)$ patient who developed into levator avulsions. No avulsions were observed in nulliparous women.

\section{DISCUSSION}

Levator ani muscle avulsion is common problem in women after vaginal delivery and it is likely to be an etiological factor in the development of female POP, especially cystocele and uterine prolapse. ${ }^{1}$

Table 1. Demographic Characteristics of the Patients

\begin{tabular}{lccc}
\hline \multicolumn{1}{c}{ Characteristics } & Nulliparous (mean (SD)) & Primiparous (mean (SD)) & Multiparous (mean (SD)) \\
\hline Age (years) & $31.4(3.2)$ & $27.0(21.0-42.0)^{*}$ & $46.3(9.5)$ \\
Highest birth weight $(\mathrm{kg})$ & - & $2.9(0.6)$ & $3.1(0.4)$ \\
Body mass index $\left(\mathrm{kg} / \mathrm{m}^{2}\right)$ & $23.2(3.1)$ & $22.8(3.2)$ & $26.1(3.7)$ \\
\hline \hline
\end{tabular}

*Median (min-max) 
Acute levator ani muscle injury can be diagnosed clinically through visualization and digital examination; whereas, levator avulsion is associated with large vaginal tear. ${ }^{2}$ Chronic detachment of the levator ani muscle from the inferior ramus of pubic bone can be evaluated by palpation. ${ }^{3}$

The incidence of levator ani muscle avulsion following vaginal delivery in our study was around $2.2 \%$ and it could be found in primiparous or multiparous women. Previous studies had shown higher incidence rate of levator ani muscle avulsion, namely $36 \%{ }^{4}$ and $21 \%{ }^{5}$. The very low incidence rate in our study might be occurred because we only reported major levator ani muscle avulsion; meanwhile, the minor levator ani muscle avulsion was not counted in.

It is estimated that levator ani muscle injury happens not only during delivery but also during the period of pregnancy. During gestation, the gravid uterus enlarges progressively, inducing its effect on the levator ani muscle, probably through three mechanisms. The mechanisms are an increment of the uterine weight, an elevation of the intraabdominal pressure, and a mechanical interference with its functional activity. Continuously, the uterine weight increases during gestation, reaching its maximum weight during several final weeks of gestation. The levator ani muscle has to bear this weight. At the expense of the levator plate size, the enlarging uterus widens the levator hiatal area progressively. The levator hiatus occupies the anterior part of the levator plate. The lowest part of the enlarging uterus engages through the levator hiatus, resulting progressive widening of the hiatus. Meanwhile, the uterus encroaches on the levator plate, reducing to the minimum its transverse diameter across the pelvic cavity. As a result, the levator plate sags down, leading to suspensory sling subluxation in addition to widening and lowering of the levator hiatus. Hence, most of the anal canal, urethra, and vagina lie above and they are exposed to the direct effect of the intraabdominal pressure. The lowered and widened levator hiatus exposes anal canal and urethra directly to the intra abdominal pressure on straining at defecation or urination. Then, it is transmitted through the abnormally wide levator hiatus to the anal canal and urethra leading to their obstruction. It is predicted that the high anal canal pressure recorded during levator ani muscle contraction on straining in multiparous women coming from the increased intra abdominal pressure directly to the anal canal. ${ }^{6}$ The second factor affecting the levator ani muscle during gestation is the constantly increasing intraabdominal pressure induced by the enlarging gravid uterus. ${ }^{7}$ Previous studies had stated that the main brunt of the increased intraabdominal pressure fell on the levator plate, particularly on the rectococcygeal raphe, which is the most dependent and durable part of the levator plate. ${ }^{8-10}$ Being tendinous, the rectococcygeal raphe and hiatal ligament become overstretched and subluxated. The third factor concerning the effect of the gravid uterus on the functional activity of the levator ani muscle is the mechanical factor. During last month of pregnancy, the gravid uterus mechanically blocks contraction power of the levator ani muscle, leading to interfered contraction process. $^{6}$

According to previous study conducted by Garcia-Mejido ${ }^{11}$, the most important risk factor associated with avulsion during vaginal delivery is fetal weight. Some studies had shown that birth weight is a risk factor for pelvic floor damage ${ }^{12}$ and urogenital prolapse. ${ }^{13}$ However, some studies concluded contrasting results. ${ }^{14-17}$ Avulsion leads to an enlargement of the levator hiatus, particularly in its anterior part, which is clearly associated with POP. ${ }^{20}$ It has been considered that older age is a risk factor for avulsion. ${ }^{18-22}$

Avulsion occurs more frequently in multiparous compared with nulliparous women due to greater contractibility. Zanetti, et al. ${ }^{23}$ found greater distensibility in the multiparous than in the nulliparous women (20.07 (SD 0.46) cm vs 19.3 (SD 2.8) cm; $\mathrm{p}<0.001$ ) during delivery. In addition, previous study conducted by Petricelli, et al. ${ }^{24}$ suggested that nulliparous women had higher electrical activity compared to multiparous women. The mechanical and hormonal effects of pregnancy may induce biomechanical, neurological or neuromuscular changes to the pelvic floor and pelvic organ supports $^{25,26}$ and they may contribute to pelvic floor dysfunction, independently of delivery mode. Weidner, et al. ${ }^{27}$ had demonstrated that pregnancy had negative effect on the electromyographic activity of the urethral rhabdo sphincter.

The limitation of this study included small sample size. The prevalence of avulsion in this study was very low (2.2\%); while, the differences between nulliparous and multiparous group could not be observed any further. 


\section{CONCLUSION}

It is essential to perform the measurement of the levator hiatus in pregnant women. By measuring the levator hiatus, the incidence of POP could be predicted; therefore, preventive management can be held earlier during the process of delivery.

\section{REFERENCES}

1. Dietz HP, Bhalla R, Chantasorn V, Shek KL. Avulsion of the puborectalis muscle is associated with asymmetry of the levator hiatus. Ultrasound Obstet Gynecol 2011; 37(6): 7236.

2. Dietz HP, Gillespie AV, Phadke P. Avulsion of the pubovisceral muscle associated with large vaginal tear after normal vaginal delivery at term. Aus N Z J Obstet Gynaecol 2007; 47: 341-4.

3. Schwertner-Tiepelmann N, Thakar R, Sultan AH, Tunn R. Obstetric levator ani muscle injuries: current status. Ultrasound Obstet Gynecol, 2012; 39: 372-83.

4. Dietz HP, Lanzarone V. Levator trauma after vaginal delivery. Obstet Gynecol 2005; 106: 707-12.

5. van Delft K, Thakar R, Sultan AH, et al. Levator ani muscle avulsion during childbirth: a risk prediction model. BJOG. 2014; 121: 1155-63.

6. Shafik A, El-Sibai O. Study of the levator ani muscle in the multipara. J Obstet Gynaecol. 2002; 22(2): 187-92.

7. Shafik A. A new concept of the anatomy of the anal sphincter mechanism and the physiology of defecation. Mass contraction of the pelvic floor muscles. International Urogynecol J. 1998; 9: 28-32.

8. Shafik A. A new concept of the anatomy of the anal sphincter mechanism and the physiology of defecation. II. Anatomy of the levator ani muscle with special reference to puborectalis. Invest Urol. 1975; 13: 175-82.

9. Shafik A. A new concept of the anatomy of the anal sphincter mechanism and the physiology of defecation. VIII. Levator hiatus and tunnel. Anatomy and function. Diseases of the Colon and Rectum. 1979; 22: 539-49.

10. Shafik A. Constipation: some provocative thoughts. J Clin Gastroenterol. 1991; 13: 259-67.

11. Falkert A, Endress E, Weigl M, Seelbach-Go? bel B. Threedimensional ultrasound of the pelvic floor 2 days after first delivery: influence of constitutional and obstetric factors. Ultrasound Obstet Gynecol. 2010; 35: 583-8.

12. Snooks SJ, Swash M, Henry MM, Setchell M. Risk factors in childbirth causing damage to the pelvic floor innervation. Int J Colorectal Dis. 1986; 1: 20-4.

13. Chiaffarino F, Chatenoud L, Dindelli M, Meschia M, Buonaguidi A, Amicarelli F, et al. Reproductive factors, family history, occupation and risk of urogenital prolapse. Eur J Obstet Gynecol Reprod Biol 1999; 82: 63-7.
14. Albrich SB, Laterza RM, Skala C, et al. Impact of mode of delivery on levator morphology: a prospective observational study with three-dimensional ultrasound early in the postpartum period. BJOG. 2012; 119: 51-60.

15. Shek K, Dietz HP. Intrapartum risk factors for levator trauma. BJOG. 2010; 117: 1485-92.

16. Chan SS, Cheung RY, Tui AK, et al. Prevalence of levator ani muscle injury in Chinese women after first delivery. Ultrasound Obstet Gynecol. 2012; 39: 704-9.

17. Cassado J, Pessarradona A, Espun AM, et al. Four-dimensional sonographic evaluation of avulsion of the levator ani according to delivery mode. Ultrasound Obstet Gynecol. 2011; 38: 701-6.

18. Kearney R, Miller JM, Ashton-Miller JA, DeLancey JO. Obstetric factors associated with levator ani muscle injury after vaginal birth. Obstet Gynecol. 2006; 107: 144-9.

19. Dietz HP, Simpson JM. Does delayed child-bearing increase the risk of levator injury in labour? Aus N Z J Obstet Gynecol. 2007; 47: 491-5.

20. Ecker J, Chen K, Cohen A, et al. Increased risk of cesarean delivery with advancing maternal age: indications and associated factors in nulliparous women. Am J Obstet Gynecol. 2001; 185: 883-7.

21. Bell JS, Campbell DM, Graham WJ, et al. Can obstetric complications explain the high levels of obstetric interventions and maternity service use among older women? A retrospective analysis of routinely collected data. BJOG. 2001; 108: $910-8$

22. Marsoosi V, Jamal A, Eslamian L, Oveisi S, Abotorabi S. Prolonged second stage of labor and levator ani muscle injuries. Glob J Health Sci. 2015; 7(1): 267-73.

23. MR Zanetti, Avalia ca oquantitativa da extensibilida de perineal em parturientes [Ph.D. thesis], Departamento de Obstet cia, Universidade Federal de Sao Paulo, 2010.

24. Petricelli CD, Resende AP, Elito Júnior J, et al. Distensibility and strength of the pelvic floor muscles of women in the third trimester of pregnancy. Biomed Res Int. 2013; 437867-10.

25. South MMT, Stinnett SS, Sanders DB, Weidner AC. Levator ani denervation and reinnervation 6 months after childbirth. Am J Obstet Gynecol. 2009(5); 519: e1-519.e7

26. Chen B, Wen Y, Yu X, Polan ML Elastin metabolism in pelvic tissues: is it modulated by reproductive hormones? Am J Obstet Gynecol. 2005; 192: 1605-13

27. Hunskaar S, Arnold EP, Burgio K, Diokno AC, Herzog AR, Mallett VT (2000) Epidemiology and natural history of urinary incontinence. [Review] [161 refs]. Int Urogynecol J. 2000; 11(5): 301-19. 